\title{
NOTE
}

\section{Diel vertical movement by mesograzers on seaweeds}

\author{
Cary N. Rogers*, Jane E. Williamson, David G. Carson, Peter D. Steinberg
}

School of Biological Science, University of New South Wales, Sydney 2052, Australia

\begin{abstract}
Diel vertical movement is well documented for many zooplankton. The ecology of small benthic herbivores which use seaweeds as food and habitat, known as 'mesograzers', is similar in some regards to zooplankton, and we hypothesised that mesograzers might also exhibit diel patterns of movement on host algae. We studied 3 non-swimming species of mesograzer, the sea hare Aplysia parvula, the sea urchin Holopneustes purpurascens, and the prosobranch mollusc Phasianotrochus eximius. All exhibited diel movement on host algae. This behaviour occurred on different host algae, despite variation in algal morphology and other characters. Possible factors causing diel movement by mesograzers include predation, nutritional gain, avoidance of photodamage, micro-environmental vanation near host algae, and reproductive strategies. These are discussed with regard to mesograzers and related to theories for diel vertical movement by zooplankton. The relative ease of experimental manipulation of benthic seaweeds and mesograzers makes them suitable as model systems to test theories for diel vertical movement.
\end{abstract}

KEY WORDS: Diel vertical movement - Mesograzer - Herbivore Predation UVR - Algae Aplysia parvula Holopneustes purpurascens. Phasianotrochus eximius

Diel vertical movement through the water column by aquatic invertebrates and fishes is a well-documented phenomenon. Many zooplankton and invertebrate larvae ascend to surface waters in the evening and descend to deeper waters at dawn (Roe et al. 1984, Lampert 1989). Similar behaviour has been found for infaunal benthic invertebrates (e.g. Alldredge \& King 1985 ) and crustaceans from seagrass beds (e.g. Robertson \& Howard 1978), with these animals descending into the sediments or seagrass foliage at dawn. These patterns of behaviour are thought to have fundamental consequences for the movement and redistribution of

•E-mail: cary.rogers@unsw.edu.au nutrients across trophic levels in such systems (Kitting et al. 1984, Longhurst \& Harrison 1989).

Arguably, the dominant model to explain diel vertical movement by zooplankton is avoidance of visually feeding predators in surface waters during the day (Zaret \& Suffern 1976, Stich \& Lampert 1981, Bollens \& Frost 1989). This model is supported by studies of both demersal and pelagic zooplankton (Robertson \& Howard 1978, Alldredge \& King 1985, Ohman 1990, Osgood \& Frost 1994), although the impact of predation on zooplankton varies with ontogenetic stage, food availability, and predator evasion or defence mechanisms (Bryan et al. 1995, Morgan 1995, McClintock et al. 1996). Alternative explanations for diel vertical movement by zooplankton include conservation of energy in association with vertical thermal gradients (McLaren 1974, Williamson et al. 1996), escape from physiological stress such as photodamage (Lampert 1989, Morgan \& Christy 1996), and the exploitation of phytoplankton rich surface waters at night (Enright 1977).

Predation on benthic invertebrates is also an important ecological and evolutionary force (Vermeij 1987), and avoidance of diurnally active, visually feeding predators has been suggested to be responsible for nocturnal patterns of foraging by sea urchins (Nelson \& Vance 1979) and littoral amphipods (Buschmann 1990). Small benthic invertebrates which do not attain a size which allows escape from predation should be particularly susceptible. One diverse group that fits this criterion are small herbivores or 'mesograzers' (Hay et al. 1987), which use benthic macrophytes as both a food source and habitat (Duffy \& Hay 1991، Hay \& Steinberg 1992). Predation, especially by visually feeding fishes, can strongly affect plant use by mesograzers, causing some to adopt algae as refuges (Hay et al. 1989, Duffy \& Hay 1994). Given that predation may have a similar influence on both zooplankton and 
mesograzers, we thought that mesograzers may perform diel vertical movements on host plants, sheltering amongst the basal fronds during the day and moving up towards the canopy at night.

Materials and methods. Three species of mesograzers found on subtidal reefs at Bare Island (33 $59^{\prime} \mathrm{S}$,

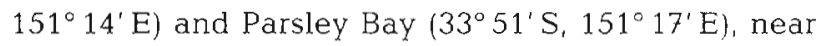
Sydney, Australia, were chosen to test this hypothesis. These were the sea hare Aplysia parvula, small specimens of the sea urchin Holopneustes purpurascens, and the prosobranch gastropod Phasianotrochus eximius. Species of algae sampled included: the red algae Delisea pulchra (Bonnemaisoniales) for all mesograzers, Laurencia obtusa (Ceramiales) for A. parvula only; and the brown algae Sargassum vestitum (Fucales) for $H$. purpurascens, and $S$. linearifolium (Fucales) for $P$. eximius. These algae were chosen because they are common host plants for the mesograzers studied, because they were abundant at the field sites, and because they differ in morphology and growth form. $D$. pulchra and L. obtusa have lateral apical growth, while $S$. vestitum and $S$. linearifolium have both diffuse apical and intercalary growth (Clayton \& King 1990). All algae studied had an extensive lateral habit. The height of algae sampled were (mean \pm standard error, in $\mathrm{cm}) 12.4 \pm 0.4(\mathrm{n}=437)$ for $D$. pulchra, $9.5 \pm 0.3(\mathrm{n}=$ 35) for L. obtusa, $15.6 \pm 0.2(\mathrm{n}=303)$ for $S$. vestitum, and $19.3 \pm 0.5(n=266)$ for $S$. linearifolium.

The vertical position of mesograzers on these algae was measured in situ using SCUBA for day and night samples. Since Holopneustes purpurascens and Phasianotrochus eximius occur in high densities at Bare Island, the vertical position of these species was sampled on randomly selected plants. In contrast, Aplysia parvula occur in lower densities on host algae (Rogers et al. 1995), and a different technique was used to measure their vertical position. This involved locating and tagging 20 plants containing sea hares and returning to tagged plants after $12 \mathrm{~h}$ for measurements. Tags were relocated to other plants if the sea hares emigrated. Sampling was repeated for A. parvula on Delisea pulchra in order to assess if torch-light disturbance affected the pattern of vertical distribution, first tagging plants during daylight and returning at night (23 May), and vice versa (13 August 1996).

The vertical position of mesograzers on host plants was quantified as the proportion of each individual's position on the plant to the total height of the plant above the substratum. Field sampling involved measurements of the height of each host plant from the holdfast to the central apical tips, and the position of each mesograzer on the plant, measured from the holdfast to the point intersecting the centre of the animal. Care was taken to ensure that the mesograzers were not touched during this procedure. The position
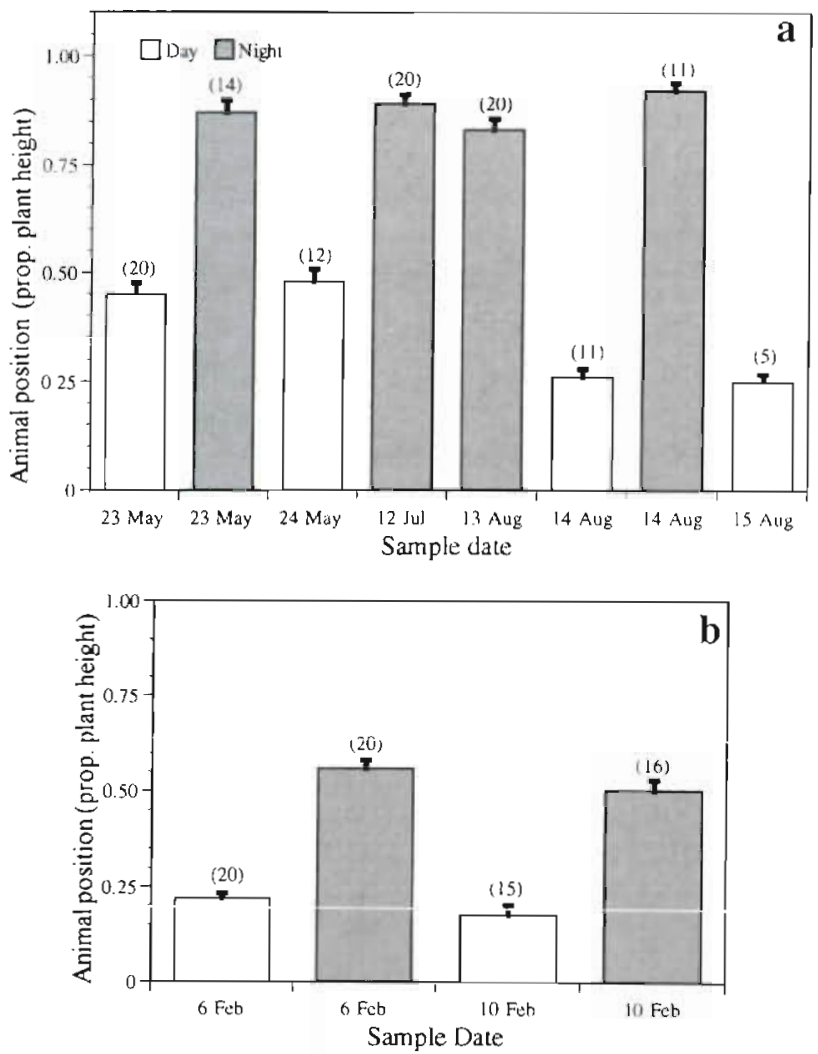

Fig. 1. Aplysia parvula, Vertical position of sea hares as a proportion of plant height (mean + standard error) during the day and night on the seaweeds (a) Delisea pulchra at Bare Island and (b) Laurencia obtusa at Parsley Bay. Number shown above bars is the number of plants sampled $(n)$

of mesograzers on each host alga was averaged per plant to give replicate measures, in order to avoid problems with possible non-independence among mesograzers on a single plant, and because of variability in the number of individuals per plant. Differences in mesograzer position on host algae between diel samples was tested using a 2-factor analysis of variance after transforming the data using $\ln (1+x)$. Measurements were taken on various dates for diel position (random factor), with date as a nested factor in the analyses. Data were checked for homogeneity of variance using Cochran's test (Underwood 1981) prior to analysis.

The 'visibility' of each species of mesograzer was also measured to assess their relative crypsis on Delisea pulchra during the day versus night. These data provide an estimate of the mesograzers likely to be visually detected by predators such as fishes. The number of Aplysia parvula and Holopneustes purpurascens visible on $D$. pulchra was counted along five $0.5 \times 4 \mathrm{~m}\left(2 \mathrm{~m}^{2}\right)$ transects without disturbing the alga; then each plant within the transect was carefully 

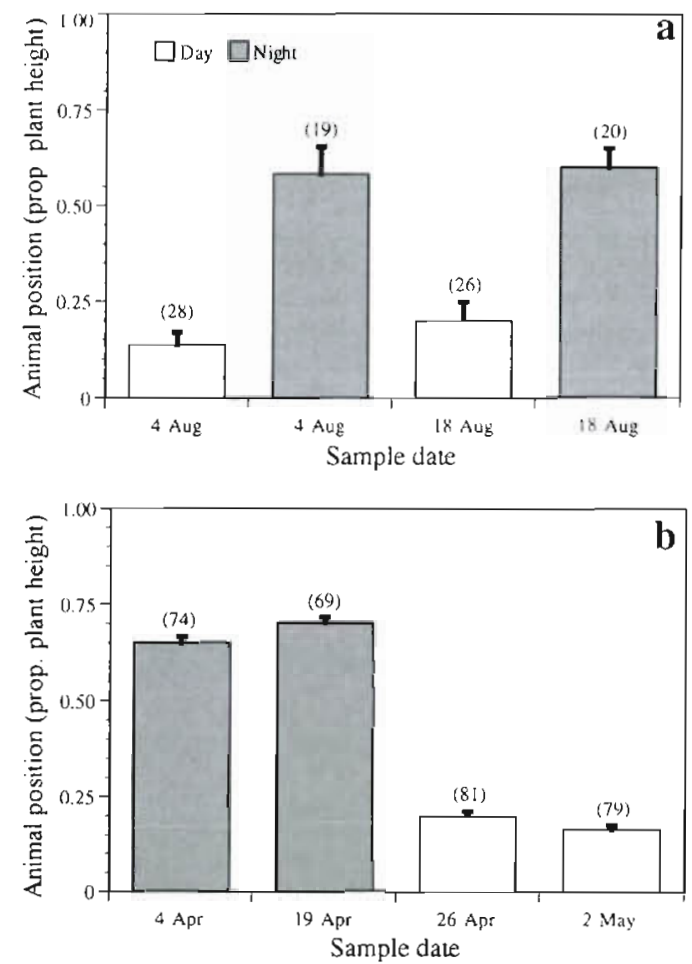

Fig. 2. Holopneustes purpurascens. Vertical position of sea urchins as a proportion of plant height (mean + standard error) during the day and night on the seaweeds (a) Delisea pulchra at Bare Island and (b) Sargassum vestitum at Bare Island. Number shown above bars is the number of plants sampled (n)

searched for mesograzers and their presence recorded to measure total abundance. The visibility and total number of the more common Phasianotrochus eximius was measured using five $0.25 \mathrm{~m}^{2}$ quadrats. The number of mesograzers visible per $\mathrm{m}^{2}$ and the transformed $[\ln (1+x)]$ proportion of individuals visible (i.e. individuals visible $\div$ total individuals per transect) were then calculated for each mesograzer species and compared between day and night using an unpaired $t$-test.

Results. All 3 species of mesograzers exhibited diel vertical movement on all host plants, occupying significantly higher positions on their host algae at night compared to during the day (Figs. 1 to 3, Table 1). Meso-
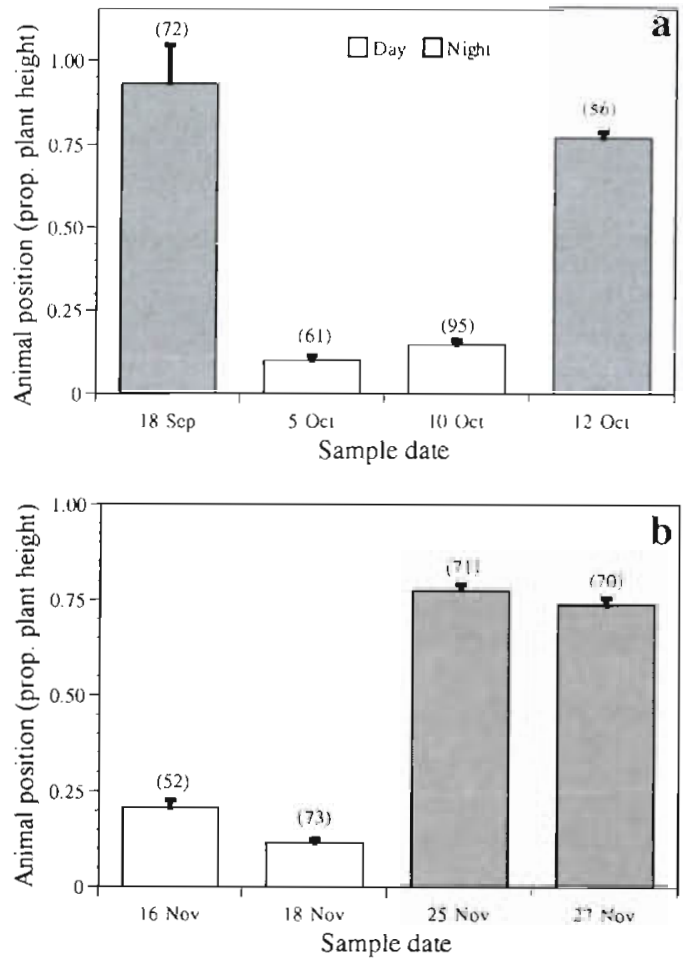

Fig. 3. Phasianotrochus eximius. Vertical position of snails as a proportion of plant height (mean + standard error) during the day and night on the seaweeds (a) Delisea pulchra at Bare lsland and (b) Sargassum linearifolium at Bare Is. Number shown above bărs is the nunver of piants sampled (n)

grazers were found in the mid to basal sections of the algae during the day, and close to the canopy region at night. Although the sampling for Holopneustes purpurascens on Sargassum vestitum (Fig. 2b) and Phasianotrochus eximius on Sargassum linearifolium (Fig. 3b) was not interspersed between times (night, and day) on consecutive dates, the pattern across mesograzers and algae is robust. All mesograzers were significantly more visible on Delisea pulchra at night (Table 2) compared to the day, when few individuals were visible on the algae. The proportion of mesograzers visible was also significantly higher at night (Table 2) than during the day, when few individuals were observed without

Table 1. Nested analysis of variance for diel variation in mesograzer position $[\ln (1+x)$ transformed] on host algae. Species of mesograzer: A.p., Aplysia parvula; H.p., Holopneustes purpurascens; P.e., Phasianotrochus eximius. Species of algae: D.p., Delisea pulchra; L.o., Laurencia obtusa; S.1., Sargassum linearifolium; and S.v., Sargassum vestitum

\begin{tabular}{|c|c|c|c|c|c|c|c|c|c|c|c|c|c|c|c|c|c|c|}
\hline \multirow{2}{*}{$\begin{array}{l}\text { Species of mesogr./algae: } \\
\text { Source of vanation: }\end{array}$} & \multicolumn{3}{|c|}{ A.p./D.p. } & \multicolumn{3}{|c|}{ A.p./L.o. } & \multicolumn{3}{|c|}{ H.p./D.p. } & \multicolumn{3}{|c|}{ H.p./S.v. } & \multicolumn{3}{|c|}{ P.e./D.p. } & \multicolumn{3}{|c|}{ P.e./S.I. } \\
\hline & df & $F$ & $p$ & $d f$ & F & $\mathrm{p}$ & df & $F$ & $\mathrm{p}$ & $\mathrm{df}$ & $F$ & $p$ & $d f$ & $F$ & $p$ & $d f$ & $F$ & $\mathrm{p}$ \\
\hline Day/Night & 1 & 54.6 & $<0.01$ & 1 & 138.3 & $<0.01$ & 1 & 144.1 & $<0.01$ & 1 & 271.0 & $<0.01$ & 1 & 219.2 & $<0.01$ & 1 & 113.7 & $<0.01$ \\
\hline Date $(\mathrm{D} / \mathrm{N})$ & 6 & 9.3 & $<0.01$ & 2 & 1.3 & 0.29 & 2 & 0.5 & 0.58 & 2 & 4.5 & 0.01 & 2 & 3.0 & 0.05 & 2 & 10.8 & $<0.01$ \\
\hline Error & 105 & & & 67 & & & 89 & & & 299 & & & 280 & & & 262 & & \\
\hline
\end{tabular}


Table 2. Aplysia parvula, Phasianotrochus eximius, and Holopneustes purpurascens. Visibility of mesograzers on the alga Delisea pulchra during day and night transects at Bare Island. Data are the number of each species visible per $\mathrm{m}^{2}$ and $\ln (1+x) \operatorname{transformed}$ proportion of mesograzers visible (mean \pm standard error). Comparisons of day/night visibility and proportion visible were done

using an unpaired $t$-test (2-tailed). Number of individuals found for each sample $(n)$ is shown under the proportion visible

\begin{tabular}{|c|c|c|c|c|c|c|c|c|}
\hline \multirow{2}{*}{ Species } & \multicolumn{4}{|c|}{ Number visible per $\mathrm{m}^{2}$} & \multicolumn{4}{|c|}{ Proportion visible $[\ln (1+x)]$} \\
\hline & Day & Night & t & $\mathrm{p}$ & Day & Night & $t$ & $\mathrm{p}$ \\
\hline A. parvula & $0.2 \pm 0.1$ & $5.7 \pm 1.5$ & -3.66 & 0.006 & $\begin{array}{c}0.04 \pm 0.03 \\
(36)\end{array}$ & $\begin{array}{c}0.81 \pm 0.09 \\
(67)\end{array}$ & -9.48 & $<0.001$ \\
\hline P. eximius & $0 \pm 0$ & $56.4 \pm 17.4$ & -3.25 & 0.012 & $\begin{array}{l}0 \pm 0 \\
(284)\end{array}$ & $\begin{array}{c}0.65 \pm 0.07 \\
(294)\end{array}$ & -21.43 & $<0.001$ \\
\hline H. purpurascens & $0.5 \pm 0.2$ & $2.6 \pm 0.6$ & -3.18 & 0.013 & $\begin{array}{c}0.13 \pm 0.06 \\
(36)\end{array}$ & $\begin{array}{c}0.63 \pm 0.04 \\
(29)\end{array}$ & -7.10 & $<0.001$ \\
\hline
\end{tabular}

searching plants. Thus, all 3 species occur significantly lower on host plants during the day, and are more cryptir as well. For Aplysia parvula (the only herbivore examined in this regard) these movement patterns were independent of when (day or night) the measurements were first taken (Fig. 1a).

Discussion. The 3 invertebrate species studied exhibited consistent diel patterns of vertical movement on all host plants examined. This parallels similar behaviour in zooplankton (Lampert 1989), many sediment infauna, and invertebrates inhabiting seagrasses (Brawley 1992). With the exception of a single nonquantitative study for crustaceans on seagrasses (Ledoyer 1969), this is the first report of such behaviour for small non-swimming invertebrates. Moreover, the species studied here, benthic gastropods and an echinoid, are as adults taxonomically quite distinct from the zooplankton and infauna which have been the focus of other studies of diel vertical movement.

Since diel vertical movement by these mesograzers parallels similar behaviour in zooplankton, the factors causing such behaviour may be common to both systems. As for zooplankton, predation by visual predators is likely to be an important influence on mesograzers. Daytime predation by the territorial damselfish Parma microlepis causes significant mortality of Holopneustes purpurascens removed from the shelter of a host plant, while urchins exposed at night are not eaten by this fish (Carson 1996). Other mesograzers (e.g. Pennings 1990, Duffy \& Hay 1994) also use host plants as refuges, and it is likely that the threat posed by visual predators such as fishes restricts mesograzers to cryptic, basal positions on host algae during the day.

However, as for zooplankton, predation cannot be the sole factor determining diel vertical movement by mesograzers since it does not account for ascent at night. One explanation for the nocturnal ascent of zooplankton is that they exploit aggregations of phytoplankton which form in the photic zone during daylight (Enright 1977). Similarly, nocturnal movement towards the canopy of algae by mesograzers may be due to variation in the nutritional qualities of different parts of host algae. All species of algae studied here have apical growth, and fast-growing apical tissues are often less tough and higher in nitrogen than the basal parts of seaweeds (Cronin \& Hay 1996). Epiphytes can be more abundant in the canopy of macrophytes, ald these additional seaweeds may also attract mesograzers to feed in this region (Brawley 1992). However, preferences for meristematic tissues (e.g. Poore 1994) or epiphytes does not fully explain nocturnal ascent by these herbivores. Both Sargassum species studied here have growth forms that include secondary meristematic regions along the entire length of the thalli (as laterals). Moreover, all 3 mesograzers readily consume their host algae, and Aplysia parvula preferentially consume Laurencia obtusa over cooccurring algae (Rogers et al. 1995, Rogers unpubl. data), including epiphytic species such as UIva spp.

Alternatively, mesograzers may move to the canopy of algae at night to avoid physiological stress caused by micro-environmental changes such as oxygen depletion, or increasing levels of harmful compounds (e.g. $\mathrm{CO}_{2}$ or secondary metabolites), which can accumulate in boundary layers (Jørgensen \& Revsbech 1985) around algal thalli. During the day photosynthesis saturates oxygen levels near macroalgae. However at night, the boundary layer may become anoxic due to algal respiration, forcing mesograzers to move up host algae to more oxygenated waters. Moreover, as light affects nutrient uptake by algae indirectly through photosynthesis (Carpenter \& Capone 1983), mesograzer waste products like ammonia that are absorbed during daylight (Bray et al. 1986, Williamson \& Rees 1994) could accumulate around algal thalli at night in levels harmful to mesograzers.

Another possibility is that mesograzers, like many zooplankton (e.g. Morgan \& Christy 1996), are adversely affected by prolonged exposure to ultraviolet radiation (UVR) and avoid the canopy region of algae 
during the day. UVR is a significant component of sunlight and can penetrate oceanic waters to $60-70 \mathrm{~m}$ depth (Smith et al. 1992). In coastal waters penetration of UVR is much lower $(<5 \mathrm{~m})$ due to attenuation by seston and gelbstoff (Häder 1997), but still relevant to the system studied here. Morphologically complex algae could provide protection to mesograzers from UVR through shading by their thalli. If UVR avoidance is an important stimulus for diel movement, then species of mesograzers that only occur on deeper seaweeds, where UVR is attenuated, should not move vertically.

Diel vertical movement may also be important for reproduction by mesograzers. For those that occur in relatively low densities and copulate, such as Aplysia parvula, nocturnal ascent to the canopy may increase the probability of finding mates. Although, we have observed A. parvula frequently copulating in the canopy of Delisea pulchra at night, mating has rarely been witnessed during the day. The canopy of benthic algae is also subject to greater water flow and dispersion than enclosed parts (Mann \& Lazier 1991), and for broadcast spawners like Holopneustes purpurascens it is probably the most advantageous part of the plant for sexual signalling (e.g. pheromones) and release of gametes.

Understanding the causes shaping the evolution of behaviour is often greatly enhanced by comparisons across taxa or systems (e.g. the 'comparative' method; Harvey \& Pagel 1991j. Zooplankton and the mesograzers studied here are taxonomically distinct and represent different ecological systems. However, diel vertical movement by both groups may well be affected by similar factors. Of these, perhaps the strongest evidence in both systems is for the influence of predation, although factors such as variable food gradients, micro-environmental changes, avoidance of UVR, or reproductive strategies may also play an important role. One advantage of mesograzer/algal systems as compared to zooplankton is the ease with which they can be experimentally manipulated (Hay \& Steinberg 1992) because of their size, relative immobility, and occurrence in accessible sublittoral systems. Thus, although diel vertical movement is much less documented for mesograzers compared to zooplankton, mesograzers and their host seaweeds can provide a suitable experimental system to test hypotheses for diel vertical movements by marine invertebrates.

Acknowledgements. We thank Alistair Poore and Rocky de Nys for comments on this manuscript, and Jeffrey Wright for assistance with night dives. C.N.R and J.E.W. were supported by Australian Postgraduate Awards during the period of this work. This research was funded by Australian Research Council grant \# A19530672 to P.D.S

\section{LITERATURE CITED}

Alldredge AL, King JM (1985) The distance demersal zooplankton migrate above the benthos: implications for predation. Mar Biol 84:253-260

Bollens SM, Frost BW (1989) Predator-induced diel vertical migration in a planktonic copepod. J Plankton Res 11 $1047-1065$

Brawley SH (1992) Mesoherbivores. In: John DM, Hawkins SJ, Price JH (eds) Plant-animal interactions in the marine benthos. Clarendon Press, Oxford, p 235-263

Bray RN, Purcel LJ, Miller DAC (1986) Ammonium excretion in a temperate-reef community by a planktivorous fish Chromis punctipinnis, and potential uptake by young giant kelp, Macrocystis pyrifera. Mar Biol 90:327-334

Bryan PJ, Yoshida WY, Mcclintock JB, Baker BJ (1995) Ecological role of pteronone, a novel antifeedant produced by the conspicuous Antarctic pteropod Clione antarctica. Mar Biol 122:215-221

Buschmann AH (1990) Intertidal macroalgae as refuge and food for amphipoda in central Chile. Aquat Bot 36: $237-245$

Carpenter EJ, Capone DG (1983) Nitrogen in the marine environment. Academic Press, New York.

Carson DG (1996) Factors affecting host plant use by the canopy dwelling echinoid Holopneustes purpurascens. Honours thesis, University of New South Wales

Clayton MN, King RJ (1990) Biology of marine plants. Longman Cheshire Pty, Melbourne

Cronin G. Hay ME (1996) Within-plant variation in seaweed palatability and chemical defences: optimal defence theory versus the growth-differentiation balance hypothesis. Oecologia 105:361-368

Duffy JE, Hay ME (1991) Food and shelter as determinants of tood choice by an herbivorous marine amphipod. Ecology 72:1286-1298

Duffy JE, Hay ME (1994) Herbivore resistance to seaweed chemical defence: the roles of mobility and predation risk. Ecology 75:1304-1319

Enright JT (1977) Diurnal vertical migration: adaptive significance and timing. Part 1 . Selective advantage: a metabolic model. Limnol Oceanogr 22:856-872

Häder DP (1997) Penetration and effects of solar UV-B on phytoplankton and macroalgae. Plant Ecol 128:4-13

Harvey PH, Pagel MD (1991) The comparative method in evolutionary biology. Oxford University Press, Oxford

Hay ME, Duffy JE, Pfister CA, Fenical W (1987) Chemical defence against different marine herbivores: are amphipods insect equivalents? Ecology 68:1567-1580

Hay ME, Pawlik JR, Duffy JE, Fenical W (1989) Seaweed-herbivore-predator interactions: host-plant specialisation reduces predation on small herbivores. Oecologia 81 : $418-427$

Hay ME, Steinberg PD (1992) The chemical ecology of plantherbivore interactions in marine verses terrestrial communities. In: Rosenthal GA, Berenbaum MR (eds) Herbivores: their interactions with secondary plant metabolites, Vol 2. Evolutionary and ecological processes. Academic Press, New York, p 371-413

Jørgensen BB, Revsbech NP (1985) Diffusive boundary layers and the oxygen uptake of sediments and detritus. Limnol Oceanogr 30:111-122

Kitting CL, Fry B, Morgan MD (1984) Detection of inconspicuous epiphytic algae supporting food webs in seagrass meadows. Oecologia 62:145-149

Lampert $W$ (1989) The adaptive significance of diel vertical migration of zooplankton. Funct Ecol 3:21-27 
Ledoyer M (1969) Écologie de la faune vagile des biotopes méditerranéens accessibles en scaphandre autonome. V. Étude des phénomènes nycthéméraux. Tethys 1:291-308

Longhurst AR, Harrison WG (1989) The biological pump: profiles of plankton production and consumption in the upper ocean. Prog Oceanogr 22:47-123

Mann KH, Lazier JRN (1991) Dynamics of marine ecosystems. Blackwell Scientific Publications, Oxford

McClintock JB, Swenson DP, Hargrave B, Steinberg DK, Michaels AA (1996) Feeding-deterrent properties of common oceanic holoplankton from Bermudian waters. Limnol Oceanogr 41:798-801

McLaren IA (1974) Demographic strategy of vertical migration by a marine copepod. Am Nat 108:91-102

Morgan SG (1995) Life and death in the plankton: laryal mortality and adaptation. In McEdward L (ed) Ecology of marine invertebrate larvae. CRC Press, Boca Raton, p 279-321

Morgan SG, Christy JH (1996) Survival of manine larvae under the countervailing selective pressures of photodamage and predation. Limnol Oceanogr 41:498-504

Nelson BV, Vance RR (1979) Diel foraging patterns of the sea urchin Centrostephanus coronatus as a predator avoidance strategy. Mar Biol 51:251-258

Ohman MD (1990) The demographic benefits of diel vertical migration by zooplankton. Ecol Monogr 60:257-281

Dsgonnd KE. Frost BW (1994) Ontogenetic diel vertical migration behaviours of the marine planktonic copepods Calanus pacificus and Metridia lucens. Mar Ecol Prog Ser $104: 13-25$

Pennings SC (1990) Predator-prey interactions in opisthobranch gastropods: effects of prey body size and habitat complexity. Mar Ecol Prog Ser 62:95-101

Poore AGB (1994) Selective herbivory by amphipods inhabit-

Editorial responsibility: George Humphrey (Contributing

Editor), Sydney, Australia ing the brown alga Zonaria angustata. Mar Ecol Prog Ser 107:113-123

Robertson AI, Howard RK (1978) Diel trophic interactions between vertically-migrating zooplankton and their fish predators in an eelgrass community. Mar Biol 48:207-213

Roe HJS, James PT, Thurston MH (1984) The diel migrations and distribution within a mesopelagic community in the North Eastern Atlantic. 6. Medusae, ctenophores, amphipods and euphausids. Prog Oceanogr 13:425-460

Rogers CN, Steinberg PD, de Nys R (1995) Factors associated with oligophagy in two species of sea hares. J Exp Mar Biol Ecol 192:47-73

Smith RC, Prézelin BB, Baker KS, Bidigare RR, Boucher NP, Coley T, Karentz D, Macintyre S, Matlick HA, Menzies D, Ondrusek M, Wan Z, Waters KJ (1992) Ozone depletion: ultraviolet radiation and phytoplankton biology in Antarctic waters. Science 255:952-958

Stich HB, Lampert W (1981) Predator evasion as an explanation of diurnal vertical migration by zooplankton. Nature 293:396-398

Underwood AJ (1981) Techniques of analysis of variance in experimental marine biology and ecology. Oceanogr Mar Biol Annu Rev 19:5i3-605

Vermeij GJ (1987) Evolution and escalation. Princeton University Press, Princeton, NJ

Williamson CE, Sanders RW, Moeller RE, Stuztman PL (1996) Utilisation of subsurface food resources for zooplankton reproduction: implications for diel vertical migration theory. Limnol Oceanogr 41:224-233

Williamson JE, Rees TAV (1994) Nutritional interaction in an alga-barnacle association. Oecologia 99:16-20

Zaret TM, Suffern JS (1976) Vertical migration in zooplankton as a predator avoidance mechanism. Limnol Oceanogr 21: $804-813$

Submitted: October 24, 1997; Accepted: March 27, 1998 Proofs received from author(s): May 4, 1998 